\title{
ANÁLISIS
}

\section{China's Special Economic Zones: Facing the challenge of the WTO}

DOI: $10.32870 /$ mycp.v12i35.324

Athziri M. Moreno Romo ${ }^{1}$

\section{Introduction}

7 he policy of reform and openness has brought drastic changes in the Chinese economy and society. However, one of the most important 1 changes has been the establishment of the Special Economic Zone (SEZs), which were designed to experiment with different market economy reforms and be the engine of growth in the country.

Before 1978 the Chinese government believed the international market to be a risky opponent that had to be controlled. However, the leaders gradually learned that the thirty years of inwardly-oriented development policies were ineffective in accelerating China's economy. After Mao's death, in the decade of the 1980's China started to gradually adopt outwardly-oriented development policies, which would provide an invaluable source of export revenue, technological innovation and capital financing.

Now, after more than three decades of struggle and exploration, China's SEZs have played a tremendous role in pushing forward China's reform, opening to the outside world and economic development. Nonetheless, China's

1. Actualmente está por concluir estudios de Maestría sobre China, en la Universidad Tecnológica de Sydney, Australia. 
SEZs have been under constant changes in order to adjust with world market economy, and now with the WTO's rules.

The WTO presents new challenges since two of the most important WTO's rules, namely Most Favoured Nation (MFN), and National treatment could contradict China's SEZs incentive policies. In this regard, certain measures imposed by China in connection with the SEZs may be in conflict with WTO disciplines. Of greatest concern are export subsidies and requirements to use domestic over imported goods, inconsistent with MFN and national treatment principles.

When in December 2001 China became a member of the WTO, the country promised not only to reduce tariff and non tariff barriers but also to open up sectors that were closed

Now, after more than three decades of struggle and exploration, China's SEZs have played a tremendous role in pushing forward China's reform, opening to the outside world and economic development before such as telecommunication, banking and insurance. In this case, China not only couldn't choose to gradually apply these commitments first in the SEZs, but had to do it for the whole country. Notwithstanding, the SEZs were the most prepared to comply with these rules.

Throughout the years, the SEZs have been losing their "special" status, for they no longer are the only possible areas for investment, although they remain with special investment laws for foreigners and land use incentives, making them the most attractive cities for investment among those now open to FDI. The SEZs have a tremendous geographical advantage above other regions.

With all this in mind and China undergoing such dramatic change and now being part of the WTO, one cannot help but ask the following questions: Why did China decide to establish Special Economic Zones? Why did the government decide to establish them in those particular locations? What makes the SEZs special? Have they lost or are losing their special status to other regions, as the open coastal cities or to inland Provinces? How the goals and tasks of the SEZs have been changing to match WTO's rules? What challenges they face? Where are these SEZs headed? 
Certain advantages of the SEZs are being spread to other areas of the country, although no other region has received the full package of incentives that have made the SEZs unique, not even the 14 coastal cities. Nonetheless, the SEZ's remain the preferential areas for investment and new projects, for they have the stability and experience that the investors look for. The purpose of this article is to analyze the challenges that WTO represents to the SEZs and how these zones have changed in respect with the ongoing Chinese government's reforms in compliance with WTO's, and still continue to be special.

The structure of this article will cover in the first part, the background of the establishment of the SEZs, describe what is a Special Economic Zone, what gives them the 'special' status, when and why the Chinese government decided to establish them in those particular cities, their incentives and the controversy they caused at some point in time and how they had overcome it. The second part will discuss the evolution of the SEZs, China's accession to the WTO, and how the principles of WTO could contravene the rationale of the SEZs, such as special treatment, incentive policies and privileges, among others. Thus, the analysis would be upon the challenges of the SEZs after China's accession to the WTO and how the central and local governments responded and are still dealing with the new circumstances.

\section{Historical Background of the SEZs}

Since the open door policy began in 1979, China's economic development has improved considerably, and the establishment of China's Special Economic Zones was part of that strategy that helped China's economic growth. In July 1979, the Central Committee of the Chinese Communist Party approved document 79.50 that granted, Guangdong and Fujian Provinces, powers in economic and foreign trade activities. Such document established SEZs in Shenzhen, adjacent to Hong Kong and Zhuhai, near to Macao; Xiamen, major port city and across from Taiwan and Shantou a traditional overseas Chinese town ${ }^{2}$. Furthermore, the adoption of a sound macroeconomic policy allowed China to maintain a steady and solid economic growth during this period. This growth has been possible mainly because of China's strengths: relatively stability, a remarkably high saving rate, pragmatic reforms, a disciplined labour

2. Reardon 2002, 199. 
force and a growing administrative capacity. When the SEZs were conceived, nobody could foresee the dynamism it would bring to China.

Before the reform of the foreign system and decentralisation began in 1979, China's foreign trade was similar of that of the Soviet Union. Almost all transactions were conducted by the Ministry of Foreign Trade (MOFT), and by the Foreign Trade Corporation (FTCs). The MOFT used to carry out the tasks of establishing the plan for foreign trade; establishing the contact of potential clients with local Chinese producers; verifying that all foreign trade transactions were compatible with national priorities and regulating and administrating customs ${ }^{3}$.

The complexity and extent of policies initiatives and administrative restructuring that the process of reforming a centrally planned economy requires is tremendous, and China was a great laboratory of experiments to see this happen. The openness of the country started with the SEZs, that later extended to form a coastal belt from north to south, to attract investment from Japan, South Korea, Taiwan and the Southeast Asian countries, as well as from the United States and Europe.

The establishment of these SEZs implied to carry out a full research study. As Lawrence ${ }^{4}$ pointed out, at that time Jian Zemin, vice-chairman of the State Administration Commission on Import and Export Affairs, led a delegation to study nine Economic Processing Zones (EPZs) in Sri Lanka, Malaysia, Singapore, the Philippines, Mexico, and Ireland in September and October 1980. While in Geneva, the delegation held talks with UN researchers concerning the establishment of such zones. Chinese researchers also conducted extensive studies on the development of world EPZs, with special attention to those in Taiwan, South Korea, the Philippines, Malaysia, Thailand, India and Sri Lanka. But the SEZ's goals were far more complex that those EPZs in the world economy and the Chinese SEZs have been the largest in the world in terms of area, population, and economic infrastructure.

Originally, the SEZs goals were: to attract foreign investment, earn foreign exchange by exporting, import foreign technology and management skill and acquire efficient production ${ }^{5}$. The SEZs were expected to attract FDI and

3. Oborne 1986, 36.

4. Reardon 2002, 200.

5. Webber, Wang \& Ying 2002, 146. 
advance technology for their development, as well as to establish an export oriented economy.

Although, we should not leave aside the political argument that motivated the creation of these zones as well: Hong Kong and Macao, which were to be return to China in 1997 and 1999 respectively under the slogan "one country with two systems". This means that the SEZs, were experiments that would allow the government to become familiar with the management of market economy and it would gain confidence from Hong Kong and Macao.

According to Oborne, ${ }^{6}$ in creating the SEZs the Chinese authorities made it clear that the zones were part of a strategy to modernize the country by importing at minimum costs. The SEZs were doors allowing goods and services into the country; and they were also a window, permitting a picture of China to foreigners. The zones were designed in part to provide new inputs to domestic industries; both an import substitution and export promotion strategy are cited frequently by Chinese authorities in justifying the creation of the SEZs.

One important characteristic of Chinese reform has been gradualism, as it is represented by the Chinese saying: "crossing the river by feeling the stones".? And the SEZs have been used as a laboratory for new policies and reforms, including reforms to planning, distribution, foreign trade, foreign exchange management, land management, labour management, and government administration. Of these, the ones that were successful were implemented in the rest of the country.

Another argument in accordance with that vision is the one sustained by Susan Shirk ${ }^{8}$ who emphasizes that one important characteristic of Chinese reform both at domestic and foreign level is "particularistic contracting", which means that the arrangements for foreign trade and investment are negotiated for each unit, namely province, locality or firm. According to this concept, a small number of units were chosen to be experiments that were allowed new freedoms and were given preferential treatment to guarantee a successful experiment.

\footnotetext{
6. 1986,35 .

7. Webber, Wang, Ying 2002, 166.

8. $1996,198$.
} 
For Shirk, ${ }^{9}$ the particularistic contracting model was successful because it followed the familiar pattern by which production, supply, and trade quotas were bargained out, throughout this way enterprises and localities could make sure they were no worse off by implementing reforms. In Shirk words: "the particularistic contracting is a system that was better off for the losers under the open door policy than would have been the anarchy of the market".

In December 2001 China formally joined the WTO, after fifteen years of negotiations and after reaching an agreement with United States. But China reached the gates of the WTO in different shape from other members, with a reconfigured domestic economy, actually by the time China joined the WTO it was perhaps one of the most open of all developing countries. Its tariffs and non tariffs were falling rapidly, and inflows of FDI after its accession increased in a high rate.

China has the world's second largest economy by purchasing power parity (PPP), surpassing Japan, India and Germany. It has the world's largest foreign capital reserves. It enjoys a trade surplus of US $\$ 262$ billion with the United States. It is a leading destination for FDI, and has become more integrated into the world economy through its accession to the $\mathrm{WTO}^{10}$.

According to China's 2008 WTO trade review, in 2006, foreign investment inflows to China reached US $\$ 69.468$ billion, down $4.06 \%$ from 2005 , making China the fourth largest destination in the world. FDI attracted by China in 2006 accounted for $6.72 \%$ of global foreign direct investment flows, $1.5 \%$ lower than of 2005. In 2007, FDI amounted US $\$ 78.339$ billion, slightly above the figure for $2006^{11}$.

In the post WTO era, China is expected to dismantle central planning and border protection, decentralize and liberalize trade, relax exchange controls, reduce exchange rate distortion, and remove anti-export biases in the trade regime; also China needs to expand its exports of labor intensive goods, increasing the competitive pressure on its partners with similar export structures. The SEZs are ready to most of this challenge, and other local and state governments are working on it. ${ }^{12}$

9. op.cit.

10. WTO 2008.

11. Op.cit.

12. Ramesh \&Yang 2002, 159 
The Establishment of the SEZs

What is a Special Economic Zone?

The best concept that could describe what a Special Economic Zone is giving by Jung-Dong Park: ${ }^{13}$ "A Special Economic Zone is an area in which a comparatively freer management system and other conditions are set up for the achievement of economic objectives. It enjoys economic cooperation with foreign corporation in various relationships, ranging from mergers to independent management, and is an overall economic development area in which disparate business, such as manufacturing, agriculture, livestock, fishing, commerce, housing, tourism, banking, and insurance, are conducted".

To complete this concept, a SEZ is frequently physically secured, but not always, outside the customs territory of the host country. Businesses located within SEZs are normally eligible for benefits such as duty and tax exemptions on goods based on the fact that they are physically located within the zone.

China's Special Economic Zones are special areas open to foreign businesses; finance and trade, the most common forms of cooperation that takes place are sino-foreign joint ventures and partnerships as well as wholly foreign-owned enterprises.

SEZs are not new, they are a long established part of international trade. 'Entrepots', warehouses where merchandise can be stored, manipulated, and in some cases processed, without the payment of duties and taxes, have existed for many centuries. City wide free zones on international trade routes were also common. Starting in the late 1970's, China used SEZs to pioneer new economic policies, provide modern infrastructure and attract investment for export oriented industries. A 2008 WTO trade policy review of China found that as of 2006 there were 660 SEZs and other development zones approved by local governments. However, this research focus only on the first 5 SEZs where the reforms took place gradually.

The SEZs were granted with greater independence on international trade activities as well as with special tax incentives for foreign investment. The initial objectives of China's SEZs were: 1 ) transfer of hi-tech industries into the SEZs, 2) experiment and acquisition of modern technology and management expertise, 3) creation of employment, 4) earning of foreign exchange through

13. 1997,11 . 
exports, 5) promotion of economic development and regional development, 6) creation of economic links to the domestic economy with Hong Kong (close to Shenzhen), Macao (close to Zhuhai), Taiwan (close to Xiamen) and overseas Chinese communities (Shantou), 7) experiment of new economic reform with market forces and 8) setting up a link between the economic inland and overseas ${ }^{14}$.

Accordingly to Park ${ }^{15}$ two of the most important distinction bewteen the SEZs and the zones that are not, are ownership and the economic management system. From the ownership side, foreign owned companies in the SEZs reflect a capitalism nature. From the economic management side, these foreign companies are indirectly controlled by the Chinese planned economic system. Furthermore, the zones display characteristics of both socialism and state capitalism.

But many characteristics of the SEZs are shared by other types of economic areas that can help establish external linkages with the international markets as the Export Processing Zones (EPZ) do. The SEZs and EPZs are both a variation of a free trade zone, but the physical space of the SEZ is generally much larger than the average size of the EPZs. The SEZ's economic activity is far more extensive covering a wide range of business activities whereas the EPZ mainly focused on processing and assembly in the manufacturing industry for export. ${ }^{16}$

The SEZs differed from the EPZs in the transfer of high technology industry into the SEZs, and experiment of new economic reform with market forces. But the fundamental difference between the two is that the EPZs operate in a market economy, while the SEZs are set in a centrally planned environment.

Why China established the first SEZs in Guangdong and Fujian Provinces (south of the country)?

Many authors ${ }^{17}$ agree with three major reasons why China established the first SEZs in Guangdong and Fujian Provinces. First, China promised one state -

14. Oborne 1986, Park 1997.

15. $1997,13$.

16. Ota 2003, 5.

17. Park 1997; Oborne 1986; Phillip \& Yeh 2005; Jia 1994; Webber, Wang \&Ying 2002. 
two systems to Hong Kong, Macao and Taiwan. Thus the SEZs were in close proximity to these areas so the government could become familiar with the operation of capitalism production and the market economy while learning how to manage a market economy. Second, the potential economic power of overseas Chinese, and strong businessmen from Hong Kong, Macao and Taiwan, enabled the SEZs to access information, technology and management know- how. Third, the selection of the SEZs location far away from the major centers of population and industry was to confine possible disruptions to the rest of the country; but if the economic reforms carried out in the SEZs were successful in achieving economic development then those strategies were to be spread out in the rest of the country.

At the initial stage, the SEZs were divided in two types: 1 ) special economic zones (Shenzhen and Zhuhai), combining industrial production, foreign trade and other business and 2) export processing zones (Shantou and Xiamen) focusing on processing export goods. However by 1984, Shantou and Xiamen dramatically increased their business scope, and were unified as special economic zones as well ${ }^{18}$.

Since the establishment of the SEZs, Guangdong and Fujian Provinces were granted certain autonomy to manage their financial and foreign currency; the local government were empowered to manage the areas of planning, pricing, labor, wages, and economic activities.

In sum, the experiments conducted in the SEZs included attracting and utilizing foreign capital, acquiring advance foreign production and managerial technologies, developing a comprehensive economic structure and promoting foreign trade, and of course gain experience in economic system reforms according to the international norm. ${ }^{19}$

\section{The incentives granted to China's Special Economic Zones}

The incentive package that was created for the SEZs in 1979 included the following elements: relative independence for local planning authorities, direct access to provincial and central level planning units, tax holidays, duty free allowances, negotiated limited access to the domestic Chinese market for goods produced within the SEZs, residence and work permits for foreigners and

18. Park 1997,5

19. Ge $1999,1269$. 
income tax exemptions for foreigners working within the SEZs. This incentive package was broadened during the 80 s, by lowering taxes and extending duty free status to new categories or articles imported into the SEZs. ${ }^{20}$

For example, foreign funded enterprises engaged in production and scheduled to operate for a period of ten years or more were exempted from income tax in the first and second profit making years and were allowed a 50 percent reduction of income tax in the ensuing three years. They were also exempted from export duties and from import duties for equipment for producing export products. ${ }^{21}$ Security of land was also guaranteed together with tax deduction and the simplification of administrative procedures and for the most part this policy has also functioned to attract foreign investment. ${ }^{22}$

Since there was not blueprint to follow how to manage the market economy, the results expected for the SEZs were not evident until almost ten years later. There were no guidelines for investment or priority sectors. The provincial governments were learning along the way. The promulgation of four important SEZs laws: 1) registration of enterprises, 2) land use, 3) visas and 4) labour and wages came about in Guangdong until 1981, meaning that the framework for the operation of the SEZs was set up after the zones were in function. ${ }^{23}$

However, the first years of creation of the SEZs were not successful in attracting industry in general, and the investment share for light industry for the SEZs was relatively low in comparison with real estate investment. The SEZs attracted significant tourism, recreational, housing and retail sector which were not totally congruent with their export orientation strategy at the beginning. ${ }^{24}$

Nowadays productive industrial enterprises established in the SEZs are contributing more to SEZ's income, and the proportion of large enterprises rather than small is growing. The benefits that the SEZs have brought to China as a whole can been seen in the total export value, and the utilization of FDI for infrastructure development is another benefit.

The SEZs serve as places to which people from other parts of the country come to learn about the latest development in economics, technology and

20. Oborne 1986, 139.

21. Jia 1994, 56.

22. Hannan 1995, 341.

23. Phillip \& Yeh 2005, 119.

24. Ibid. 
management. The SEZ are a link between China and the global economy. Over seven million people live in the SEZs. Secondary industry is the largest employment sector, followed by tertiary and primary industry. ${ }^{25}$

However, throughout the years, the SEZs have been losing their "special" status, for they no longer are the only possible areas for investment, although they remain with special investment laws for foreigners, and land use incentives making them the most attractive cities for investment among those now open to FDI, and besides the SEZs have a tremendous geographical advantage above other regions. Certain advantages of the SEZs are being spread to other areas of the country, although no other region has received the full package of incentives that have made the SEZs unique, not even the 14 coastal cities that were open up after the SEZs.

\section{The SEZs controversy}

During the eighties, while the SEZs achieved quantitative impressive figures regarding commercial expansion, qualitative problems were also present. The rapid rise in industrial output value came mainly from the construction industry. Similarly, though manufacturing investment grew as a proportion of the total foreign investment, much of it was in low end assembly and processing, largely using 1960s technology. Another concern was that over 91 per cent of foreign investment in the Guangdong zones has originated in Hong Kong and Macao. ${ }^{26}$ These problems attracted the attention of China's leaders because of their impact on two of the principal goals of the SEZs: technology transfer and export expansion. At Shenzhen, Xiamen and Shantou there was also lack of new industries and newly developed technologies.

Substantial concern was also raised over the lagging export performance of the zones, particularly Shenzhen. In 1983, not only total imports outgrew exports, but even local exports (those products handled by zone trade agencies) ran behind imports from 1979 to 1981, starting to change 1982. The same year, the overall volume of exports grew far more slowly than the economy (Shenzhen’s 1983 export total of US $\$ 21$ million a disappointing 1 per

25. Webber, Wang \& Ying 2002, 147.

26. Falkenheim 1990, 20 
cent of the total Guangdong exports in the same year). Moreover, exports were concentrated in fruit and foodstuffs with "very few industrial products. ${ }^{27}$

According to Wong (1985) a more fundamental contradiction of the establishment of the SEZs, was found between the capitalistic character of the SEZs and the socialist origin of the Chinese economy. Although it was said that the SEZs were an experiment in market principles and were established primarily to augment the socialist productive force, the success performance by the SEZ would undoubtedly exert unwanted pressure on the socialist system by affirming the superiority of the market economy.

Moreover, the evidence of extending the preferential policies and flexible measures to a larger area outside of the SEZs came in April 1984 with the establishment of 14 coastal cities, and the opening of more cities in 1985 and 1988. As a result, the interior region became more concerned for the flow of skilled workers to the SEZs, and the emphasis given to some region over other, increasing the disparities of economic development among regions.

It was a matter of time that the rest of the country demanded preferential treatment similar to those enjoyed by the SEZs and their coastal counterparts. In March 1995, leadership from Guangdong SEZs clashed with the Central leadership over the roles of the SEZs at the sessions of the National People's Congress. The local bosses demanded grater flexibility and more autonomy from the central government. They urged for reform in customs and border management, expansion of their bonded warehousing district and even authority to issue passports to residents in SEZs. Although some concessions were made, the Central leadership directed the SEZs to focus on active participation in the global market. There was obvious disagreement with regard to the direction that the SEZs should take. ${ }^{28}$

At the same time, some people began to argue openly that the special zones should no longer be "special". First, because similar preferential policies enjoyed by the SEZs were also introduced to the open coastal cities. Second, because of the success of the SEZs, special policies should end and they should be standing on their own feet. ${ }^{29}$ Thus, Shanghai and other regions that felt left behind responded in different ways. At the beginning they tried to sabotage the SEZs and the open policy with ideological attacks for "sell-

27. Wong 1985,65

28. Chan 1998, 437.

29. Op.cit. 
ing out the country to the foreigners". Later on, some inland regions tried to get some benefit from the SEZs, by setting up businesses there, mainly in Shenzhen. Another benefit for the inland regions was the increased demand for raw material and labor from coastal regions. In other words, the inland provinces gradually weakened their resistance and began to demand rewards of the market. ${ }^{30}$

For the Fifth Plenary session of the Fourteenth meeting of the Central Committee of the Communist Party, each province was asked to submit a report on its development strategy. Many provinces and autonomous regions in the middle and western parts of the country took the opportunity to demand the setting up of the SEZs and bonded zones in their provinces and cities so as to promote fair competition and encourage further economic development. ${ }^{31}$

However, there were still people trying to maintain the status quo, like Li Youwei, who was party secretary of the Shenzhen SEZ in the mid 90's. He argued that the SEZs serve as the "window" as well as the "arena for experimenting various policies", all contributing to a perfect socialist market economy. He described the SEZs as "soldiers in the front line" in the battlefield. The capital generated at the SEZs was been diffused to other parts of the country in cash and in kind. Li even accused those proposing to abolish the SEZ policy as being against the reform strategy initiated by the "Chief Architect". ${ }^{32}$

In 1995, Hu Ping, Director of the SEZ Office of the State Council, tried to break the debate over the abolition of the SEZs. Hu quoted Deng's idea on selected development as the precursor to market socialism. He also noted the contribution of the SEZs in accumulating experience for various policy initiatives and reforms, especially in the realm of foreign trade and direct investment. ${ }^{33}$

In December 1995, Jiang Zemin made it clear the determination to develop the zones and that this policy was going to remain unchallenged and unchanged; moreover, the historical roles and functions of the zones in the

30. Shirk 1996, 202.

31. Chan 1998, 437.

32. cited from Chan 1998, 438.

33. Chan $1998,438$. 
reform, the opening up and modernization construction was going to remain unchanged. ${ }^{34}$

Along their history the SEZs have overcome many obstacles. The idea behind the SEZs was to allow foreign investment into a handful of closed and controllable locations. What happened instead was that they opened the way for the flood of overseas capital that has entered China since then. Each SEZ has settled a number of objectives to continue to be special, for example, Shenzhen's latest five year plan has selected for development in the period 2006-2010 high-tech, finance, logistics and culture as its four pillar 'industries' 35 .

Nonetheless, new challenges arise with the passing of time and with China's accession to the WTO. The success of the foreign investment to the opening and development of the Chinese economy has led to think that the zones have lost their 'special' status. Although is more difficult to attract more FDI to the SEZs, and in the Pearl River Delta thousands of factories have sprung up outside the SEZs; however, most of these are Hong Kong and Taiwanese assembly and manufacturing operations, looking for the cheapest option. Long term investments by multinationals are still concentrated in the Delta's leading zones: Shenzhen SEZ and Guangzhou Development District. ${ }^{36}$

In sum, the SEZs remain special because of the continuing infrastructure adjustments, benefits and investor incentives; security and stability (with operating records going back over two decades) and their experience with foreign companies. While China is a huge country, when it comes to finding investment locations the choice remain small for most companies, and especially for manufactures. Although, nowadays it is possible to explore other locations, the SEZs offer by far the biggest advantages to the majority of companies looking to enter or expand in China, and they will continue to do so in the future. For many foreign firms, remaining 'in the zone', could be considered an appropriate description of one of the factors still required for success in China.

34. Chan 1998, 439.

35. Business China 2006, 3.

36. Business China 2006, 7. 


\section{The Evolution of the SEZ: trends and dynamics}

The economic performance of the SEZs and types of problems inherent to the SEZs varied at each stage of development. As an experiment field, the SEZs have been used as a platform on which to implement a series of new policies and systems. Many reforms, including reforms to planning, circulation, foreign trade and foreign exchange management, land management, labor distribution, personnel management, and government administration, pricing, and banking, were first implemented in the SEZs before introduced in any other part of the country. The SEZs became an important catalyst for regional development that provided services both locally and nationally. ${ }^{37}$

The first stage was from 1979 to mid 80s, when the industrial foundation of SEZs was laid. During this stage, all SEZs concentrated on the construction of infrastructure to create a better investment environment. They constructed groups of factory buildings, commercial buildings, tourist facilities and residential buildings. Nearly 900 new factories went into operation. ${ }^{38}$

However, the performance of the SEZs during this period was not the expected, as a limited amount of FDI flowed into the SEZs, and took form of small scale intermediate processing industrial products of labor intensive, low value added goods. Some criticisms were that Shenzhen failed in its role to achieve technology transfer, earning foreign exchange and create employment. External capital invested in Shenzhen was at first channeled toward the tourist and real state sectors. The most popular form of investment was through cooperative operation or cooperative joint ventures to reduce the risk. ${ }^{39}$ In 1984 , the government decided to extend the experiment of the SEZs and open another fourteen coastal cities granting them similar preferential incentives to the SEZs. In 1985, Pearl River Delta, South Fujian Delta and Yangtze River Delta were declared open areas as well.

The second stage started in 1986 to 1992, when the industries in the SEZs diversified. The level of foreign invested projects raised, export trade volume increased and their export oriented economy was reinforced. Investment in industry was mainly from foreign capital. In 1992, the number of approved foreign invested projects in the five SEZs was around 5,385 with a capital of

37. Webber, Wang, Ying 2002, 148.

38. Op.cit. 151.

39. Ota 2003, 19. 
US\$ 8.71 billion. In Shenzhen, Zhuhai and Xiamen, the industrial output of foreign owned enterprises made up over 50 per cent of the cities total. The firms in the SEZs gradually began to produce commodities to their own designs and production techniques instead of processing supplied materials, and the firms started to import materials and give them more added valued and exported them. ${ }^{40}$

Employment creation was generated by the inflow of FDI, although accompanied by inflation as land prices increased as well as the rents and the commodities. The income per capita rose more than the national level. All of this started to produce disparity between the SEZs and the rest of the country.

During the third stage from 1993 to the end of the 90s, the SEZs began to create new forms of international and domestic competitiveness to strengthen their development. New sectors were opened to FDI such as real state, tourism, finance, among others. The total foreign trade reached US\$27.8 billion (15 per cent of the national total in 1993). ${ }^{41}$

The open coastal cities achieved great economic development, especially Shanghai, but regional disparities did not improved. For this reason the government set as target, in the $9^{\text {th }}$ Five Year Plan (1996-2000), to reduce regional income disparity through granting the same open status to inland cities. According to the $9^{\text {th }}$ FYP, the inflow of FDI was to be used to modernize industrial structure by shifting labor intensive to technology and knowledge intensive industry. But as Warr (1998) highlighted, EPZs ran into troubles when a developing country reached a certain stage of industrial development that pushed up wage level resulting in a shift in production of high value added products and high tech industry.

The fourth stage, the WTO era, 2001 to present. Anticipating the requirements of entry, China undertook a series of measures, including the abolition of export subsidies (1991), publication of trade regulations (1992), unification of the foreign exchange value (1993), and progressive tariff reductions (1994-1997). ${ }^{42}$

China committed itself to ensure uniform and transparent administration of its trade regime subject to judicial review. The provision of WTO Agree-

40. Webber, Wang, Ying 2002, 152.

41. Op.cit. 148

42. Paltiel 2007, 140. 
ment and the Protocol apply uniformly to the entire customs territory of China, including border trade region and minority autonomous areas, Special Economic Zones, open coastal cities, economic and technical development zones and other areas where special regime for tariff, taxes and regulations are established. ${ }^{43}$

China agreed to fully comply with the Trade Related Investment Measures (TRIMs) Agreement upon accession, which required the elimination of trade-restrictive and distorting investment measures, for example, those that required local content or trade balancing or those that restricted a firm's access to foreign exchange or level of exports. China committed to ensure that the distribution of import licenses, quotas, tariff rate quotas, or any forms of import approval applied by national or sub national authorities, are not subject to conditions such as the existence of competing domestic suppliers, or performance requirements of any kind, such as local content, offset, technology transfer, export performance or the conduct of research and development in China. ${ }^{44}$

Since the establishment of the SEZs to China's accession to the WTO, it can be seen the trend of attracting foreign companies to invest in China and thereby nurturing China's economic revitalization, has been the same. Although, the new trend is trying to shift labor intensive to technology and knowledge intensive industry.

With respect to the dynamics of the SEZs, they have been changing according to the circumstances, and now they have to comply with WTO's rules. Some of the dynamics still prevail: granting tax breaks, the ability to repatriate profits and capital investments, below market lease rates for land, government financed hiring/training, employee housing and various customs exemptions, among others. Others dynamics are recent, like the open up of new sectors to FDI, which were not allowed before such as real state, tourism and finance, among others. These dynamics are particularly attractive, but not exclusively to manufacturers, but to third-party logistics providers and other companies that are engaged in importing and exporting goods to and from China.

43. OECD 2002, 755.

44. Op.cit. 756 
China's accession to the WTO

China's commitments under WTO represent the consolidation of the 37 bilateral agreements with the United States, the European Union, and the other WTO members. This consolidation is based on the principle of most favoured nation, under which the most favourable concession made to any one country in a given area is automatically extended to all other members. In December 2001, China became a member of the WTO. China promised not only to reduce tariff and non tariff barriers but also to open up sector that were closed before such as telecommunication, banking, and insurance..$^{45}$ The reasons that motivated China to initiate the process to become a member of the General Agreement on Tariff and Trade, GATT (predecessor of the WTO) in July 1986 were, first to seek membership of all multilateral institutions where membership was considered a badge of global influence, and second to guarantee access to major markets for Chinese exports.

China's initial strategy to seek membership in GATT was with the assumption of achieving market access with minimal concessions, especially over domestic governance practices. However, shifts in strategy occurred gradually, stimulated by shifts in China's economic strategy and deepening commitment to market reform; heightened desire for recognition in global economic processes and international organizations. ${ }^{46}$

Initially the process of accession seemed to be working fine, but various events delayed China's membership. The most obvious was the killing in Tiananmen Square in June 1989; after which most Western governments imposed economic sanctions on China. Then in 1991, the Soviet Union and the Council for Mutual Economic Assistance collapsed, and in 1999, the accidental bombing of China's Embassy in Belgrade, all of these events delayed the negotiation process. ${ }^{47}$ Actually, following the tragic bombing of the Chinese Embassy in Belgrade, the US signed a Memorandum of Agreement on Bilateral Terms of Accession that incorporated more modest concessions from China than those on offer half a year earlier.

The protocol of accession and the report of the working party governing China's accession to the WTO provided additional liberalization of China's

45. Lardy 2002, 2.

46. Paltiel 2007, 135.

47. Lardy 2002, 63. 
trade regime and further opening up of opportunities for foreign direct investment, the protocol also provided greater access to China's market through reduction of tariff and non tariff barriers as well as commitments to open foreign investment in the service sector.

China did not insist on be treated as developing nation for WTO accession, and was open to discussion of timetable for phase outs in particular sectors. China's willingness to make concession was accelerated further by the Asian Financial Crisis of 1997, which gave greater urgency to China's need to institutionalize a stable climate for trade and investment. Instead of seeking to eliminate competition in infant industries, China turned to international competition to accelerate domestic restructuring. ${ }^{48}$

There have been some assumptions about China's accession to the WTO, such as China would not carry out its commitments and would damage the WTO's organisation, or that China would be a troublemaker for being a big actor. But after 7 years of its accession it is clear that China has been persistently implementing its commitments, which is more to say than other developing members. China has never disrupted the international trade and investment system.

As Ramesh \& Yang" ${ }^{49}$ said "China will not challenge the existing power structure dominated by the US in the WTO because is not strong enough and more importantly it has many common interest with the US". China relies on the international economic activities as a means of economic development, China would not jeopardize this.

Nevertheless, why if China was reaching economic growth and had already integrated, in a way, into the global economy decided to access the WTO and run the risk of heavy cost in the short run, especially for key sectors? One reason was that China was facing the threat of remaining outside the mainstream of the world trading system. According to Lardy ${ }^{50}$ Taiwan could be another reason why China accepted the challenge of high short term costs. After Taiwan began to seek membership in the WTO in 1992, China insisted that Taiwan could not joint until China had become a member. If Taiwan had completed negotiations, its membership should not be held up by China's delay entry.

48. Paltiel 2007, 141.

49. 2006,185 .

50. 2002,16 . 
As Paltiel ${ }^{51}$ stated: "China's accession was made possible both by a union of domestic norms with those of the international trading system and the diplomatic skills of bargaining and trade-offs that Chinese communist negotiators perfected over half a century. Lessons learned in successive rounds of tough, bilateral trade negotiations with the US during the early 90's were applied to the WTO negotiations. The promise of accession was permanent Most Favoured Nation status, which would relieve the pressure of ongoing bilateral trade diplomacy".

Thus, bargaining was a learning curve on a sector by sector basis of the costs and benefits of accession. The continue and prolong process of the accession negotiations was the most effective device the Chinese government could do to mobilize domestic actors to take seriously the costs of adjustment.

WTO's principles vs. SEZs rationale

WTO disciplines are intended to create an open and transparent international trading system in which Members follow rules that generally preclude trade restrictions except for negotiated tariffs. The benefits of the WTO system include increased economic growth, reduction of costs for consumers, universally recognized and applied trading rules, and an effective dispute resolution process.

Nonetheless, SEZs programs have not been criticized as WTO inconsistent in WTO trade policy reviews. The SEZs compromise a unique configuration of individual measures and as such must be analyzed at the level of these measures, in this regards, certain measures imposed by China in connection with SEZ programs may be in conflict with WTO disciplines. The following information shows the WTO's principles vs. SEZs rationale.

\section{Most Favored Nation principle}

A cornerstone of the WTO system is the MFN principle. It is a legal requirement to accord equal treatment to all Member regarding covered trade measures, although WTO approved regional trade agreements are an exception. The MFN principle applies to trade in goods (specified in GATT Article I), trade in services (GATT Article II), and the protection of intellectual

51. $2007,139$. 
property rights. The denial of MFN treatment has been an issue in a number of WTO disputes ${ }^{52}$.

The rational of the SEZs might contravene MFN principle if a government imposes measures that discriminate in law or fact between goods or services, based upon the country or origin.

\section{National treatment principle}

Another cornerstone of the WTO system is the national treatment principle. This principle imposes an obligation of non-discrimination between domestic and imported goods, incorporated in GATT in Article III. The denial of national treatment has been a frequent issue in WTO disputes ${ }^{53}$.

The way that China's SEZs contravened this principle is with the subsidies involving the purchase of domestic over imported goods. In 2007, China was part of a WTO dispute for measures granting refunds, reductions or exemptions from taxes and other payments. ${ }^{54}$

\section{Transparency}

GATT in his Article X imposes various requirements including the publication and administration of trade regulations. Laws, regulations, judicial decisions and administrative ruling relating to import and export matters, duty and tax rates and other charges must be published promptly to enable governments and traders to become acquainted with them. The failure to publish violates this requirement. The transparency requirement might be contravened if a government imposes generally applicable trade requirements that have not been published. ${ }^{55}$

Transparency will be a difficulty in China. In the first place, there is a cultural tradition of non-transparency throughout the history of the country, only the emperor and imperial civil servants were aware of legal proscriptions. In more recent times, since the open door policy, quite often practices of governmental agencies in implementing legislation was hidden in so called internal regulations which were only known internally. To comply with WTO standards and China's Accession Protocol, this practice will have

52. Green; Trebilcock 2007, 654.

53. Green; Trebilcock 2007; Creskoff; Walkenhorst 2009.

54. WT/DS/358/13 2007.

55. Matsushita; Schoenbaum and Mavrodis 2003, 45 
to be eliminated throughout PRC government agencies, at least with respect to such internal regulations which relate to trade in goods and services and their treatment within China.

However, some progress has been shown, MOFTEC, China's trade ministry, has tried to remedy this situation within the last few years by engaging in mass circulation of both English and Chinese hardcopy version of China's WTO Accession Protocol and the annexes and schedules which spell out the details of China's obligation.

\section{Central and local government responses}

The Marrakesh Agreement (WTO Agreement), the Multilateral Trade Agreements, and the Protocol of Accession of China are the most important components of China's WTO obligations. Specifically, section 2 of its Protocol of Accession, requires that "local regulations, rules and other measures of local governments at the sub-national level shall conform to the obligations undertaken in the WTO Agreement and this Protocol". However, there is no description of how to apply and achieve these obligations. This is the first issue encountered by the Chinese system: the domestic legal effect of the WTO Agreement. Accordingly to Qi $(2007,6)$ the PRC Constitution is not clear about the status of treaties under Chinese laws and whether a treaty can be directly applied in China without domestic legislation.

As $\mathrm{GaO}^{56}$ points out, there are two ways to apply international treaties, one is adopting them into the domestic legal system, or apply them indirectly by enacting domestic legislation based on the contents of the treaties. In the case of China, neither the Constitution nor the Law on the Procedure of the Conclusion of Treaties specifies the general approach that should be taken.

Having this debate, the most correct way to comply with this obligations, would be through enabling domestic legislation. Failure to comply with WTO obligations would imply that $C$ hina will be subject to possible sanctions under WTO rules.

Local governments have been given much flexibility to adopt measures necessary to boost local GDP growth and are allowed to benefit directly from such growth, which is the case of the SEZs. As a result, local governments have been involved in the investment and operations of local enterprises. To

56. 2007,18 . 
promote their economic interest, local governments may provide subsidies to local firms or otherwise protect them against outside competition. They may have little incentive to enforce IP laws if local enterprises profit from violations of IP rights. Their control over local courts means that it may be impossible to obtain independent and impartial judicial review of matters involving local economic interests. Moreover, the close ties between local officials and firms make it extremely difficult to combat official corruption, which has been plaguing the Chinese system and undermining the legitimacy of the regime. ${ }^{57}$

As a matter of principle, WTO rules apply to the entire territory of each WTO members, and a member is responsible for violations of WTO rules by its political subdivisions. The WTO Agreement specially permits a member to bring to the WTO tribunal complaints arising from measures taken by the local authorities of another member. Hence, if the Chinese government lacks the political will in local protectionism, other members do have the means available at the WTO to force it to take action..$^{58}$

\section{Conclusions}

Numerous reforms have first been experimented in the SEZs, and those useful ones were later introduced into the rest of the economy. These measures included redefining the role of government in the society. State owned enterprises went through many changes, for example employment is now based on labor contracts, wages and bonuses are tied to individual efforts and the performance of enterprises. Managers are now concerned with profitability and competitiveness, instead of fulfilling production quotas. More attention is paid to market conditions when decisions on production and sales are made, among other. These measures have all helped to improve the performance of state owned enterprises in the SEZs.

In contrast to the former system in which the provincial administrative districts served as economic units, economic division is now determined by the market mechanism. The SEZs have pioneered the changing economic structure of China. This structural change which transformed China's economy

57. Qi 2007, 26.

58. Op.cit. 
from a national to an international economic framework is a landmark in the history of the Chinese economy.

China's economic reform and opening up in the past 30 years and its accession to the WTO has brought about a continued improvement of its legal system, enhanced transparency of its economic and trade policies, and a much better environment for business and investment. Some of the direct result of China's accession in the WTO has been the uniform application of laws, transparency rules and rule making, non discrimination and openness, considered an effective way to achieving global integration. ${ }^{59}$

In sum, China made commitments to phase out quotas, licenses, tendering requirements, and other quantitative restrictions that restrict trade in industrial goods, some upon accession, and many other within the two following years, and the rest within five years. In addition, China committed to progressively liberalize the availability and scope of trading rights so that within three years after accession, all enterprises in China, foreign owned and domestic, will have the right to directly sell goods throughout the customs territory of China. ${ }^{60}$

Nevertheless, while the government started liberalizing the Chinese economy through the reform period, before becoming a member of the WTO, is it true that the accession induced regulatory, institutional and normative changes in the SEZs that have transformed the overall trade and investment in China. Compared to a decade ago the Chinese system is more liberalized, open and transparent. Furthermore, China adopted several important laws and regulations reflecting its transition from a planned economy to a more market oriented system with a trade regime broadly consistent with international trading practices.

The SEZs seem to be headed to continue to be the preferential investment areas and is in these zones were the rapid changes are taking place; they are keeping pace with WTO's rules. Perhaps there are more zones to make business with China, but when it comes to the SEZs they are still the most well equipped, managerial and infrastructure wise, giving them the biggest advantage over any open coastal area (and inland region) for they have experience, security and stability. miv

59. Guo 2008,341 .

60. OECD 2002, 749. 


\section{Bibliography}

Basile, Antoine \& Germindis, Dimitri 1984, Investing in Free Export Processing Zones, $1^{\text {st }}$ edn, OECD, Paris.

Business China 2006, 'Still in the Zone', Business China, The Economist Intelligence Unit, London, May 22.

Chan C.K., Roger 1998, 'The Prospect of the Special Economic Zones Policy' in Cheng, Y.S Joseph (ed.), China in the Post-Deng Era, $1^{\text {st }}$ edn, The Chinese University Press, Hong Kong, pp. 425- 452.

Cheng, Y.S Joseph 1998, 'China's Foreign Policy in the Mid 1990s' in Cheng, Y.S Joseph (ed.), China in the Post-Deng Era, $1^{\text {st }}$ edn, The Chinese University Press, Hong Kong, pp. 217-242.

Chung-Tong, Wu 1985, 'China's Special Economic Zones: Five Years After. An Introduction', Asian Journal of Public Administration, vol. 7, no. 2, pp 127-143.

Creskoff, Stephen \& P. Walkenhorst 2009, 'Implications of WTO Disciplines for Special Economic Zones in Developing Countries', Policy Research Working Paper 4892, Washignton: The World Bank.

Dwyer, Wayne 2008, 'Current Development in the Chinese Economy', Ecodate, vol. 22, no. 1, pp 1-5.

Falkenheim, Victor 1990, 'The Political Economy of China's SEZs', in Asian Journal of Public Administration, Vol. 1, no. 3. pp. 16-34.

Gao, S. Q \& Chi, F. L. 1997, New Progress in China's Special Economic Zones, $1^{\text {st }}$ edn, Foreign Language Press, Beijing.

Ge, Wei 1999, 'Special Economic Zones and the Opening of the Chinese Economy: Some Lessons for Economic Liberalization', World Development, vol. 27, no. 7, pp 1267-1285.

Green, A. \& M. Trebilcock 2007, 'Enforcing WTO Obligations: What can we learn from Export Subsdies?', Journal of International Economic Law, vol. 10, No. 3, pp 653-661.

Guo, Yingjie 2008, 'Domestic Openness in post-WTO China: Central and Local Perspectives', Journal of Contemporary China, vol. 17, no. 55, pp 339-359.

Hannan, Kate (ed.) 1995, China, Modernisation and the Goal of Prosperity. Government Administration and Economic Policy in the late 1980s, $1^{\text {st }}$ edn, Cambridge University Press, Hong Kong. 
Howell, Jude 1993, China Open its doors. The Politics of Economic Transition, $1^{\text {st }}$ edn, Harvester Wheatsheaf, United States of America.

Jia, Wei 1994, Chinese Foreign Investment Laws and Policies, $1^{\text {st }}$ edn, Quorum Books, United States of America.

Lam, W. \& Wo L. 1998, 'Leadership Changes in China' in Cheng, Y.S Joseph (ed.), China in the Post-Deng Era, $1^{\text {st }}$ edn, The Chinese University Press, Hong Kong, pp. 21-54.

Lardy, Nicholas 2002, Integrating China into the Global Economy, $1^{\text {st }}$ edn, Brookings Institutions Press, Washington, D.C.

Matsushita, M.; Schoenbaum \& P. Mavrodis 2003, The World Trade Organization: Law, Practice and Policy, Oxford: Oxford University Press.

Nadeem M. F. \& Murray, A. 2003, 'Foreign Investment. Opportunities and Custom Laws in China's Special Economic Zones', International Journal of Management, vol. 20, no. 1, pp. 110-118.

Oborne, Michael 1986, China's Special Economic Zones, $1^{\text {st }}$ edn, OECD, France.

OECD 2002, China in the World Economy. The Domestic Policy Challenges, $1^{\text {st }}$ edn, OECD Publications, France.

Ota, Tatsuyuki 2003, 'The Role of Special Economic Zones in China's Economic Development as Compared with Asian Export Processing Zones: 1979-1995', Asia in Extenso, vol. 8, no. 1, viewed 11 May 2008, < www. iae.univ-poitiers.fr>

Paltiel, Jeremy 2007, 'Hinges and latches on the open door. The normative parameters of China's WTO accession' in Zweig, D. \& Zhimin, C. (ed.), China's Reforms and International Political Economy. $1^{\text {st }}$ edn, Routledge, London, pp 131-151.

Park, Jung-Dong 1997, The Special Economic Zones of China and their Impacton Its Economic Development, $1^{\text {st }}$ edn, Greenwood Publishing Group, Inc, United States of America.

Pearson, Margaret 2007, 'Trade policy and regulatory politics. China's WTO implementation in comparative perspective' in Zweig, D. \& Zhimin, C. (ed.), China's Reforms and International Political Economy. $1^{\text {st }}$ edn, Routledge, London, pp 112-130.

Phillips, D. \& Yeh, A. 2005, 'Special Economic Zones' in Goodman S. David (ed.), China's Regional Development, $2^{\text {nd }}$ edn, Routledge London \& New York, Great Britain.

Qian, Y. \& Stiglitz, J. 1999, 'Institutional Innovations and the Role of Local Government in Transition Economies: The Case of Guangdong Province 
in China' in McMillan, J. \& Naughton, B. (ed.), Reforming Asian Socialism. The Growth of Market Institutions, 4th edn, The University of Michigan Press, United States of America, pp 175-193.

Qin, Ya J. (2007) “The Impact of WTO Accession on China's Legal System: Trade, Investment and Beyond", Social Science Research Network, electronic paper: http://ssrn.com/abstract=985321 (10/09/08)

Ramesh, A. \& Yang, Y. 2006, 'China's increasing openness. Threat or opportunity' in Honglin Zhang, K. (ed.), China as the World Factory, 1st edn, Routledge Taylor \& Francis Group, Great Britain, pp. 159-168.

Reardon C. Lawrence 2002, The Reluctant Dragon. Crisis Cycles in Chinese Foreign Economic Policy, $2^{\text {nd }}$ edn, University of Washington Press, United States of America.

Shirk, Susan 1999, 'Internationalization and China's Economic Reforms' in Keohane, R. \& Milner, H. (ed.), Internationalization and Domestic Politics, $3^{\text {rd }}$ edn, Cambridge University Press, United Kingdom, pp. 196-205.

Stoltenberg, Clyde 1984, 'China's Special Economic Zones: Their Development and Prospects', Asian Survey, vol. 24, pp. 637-54.

Webber, M., Wang, M. \& Zhu, Y. (eds.) 2002, China's Transition to a Global Economy, $1^{\text {st }}$ edn, Palgrave Macmillan, Great Britain.

Wong, K.Y. 1985, "Trends and Strategies of Industrial Development", in Modernization in China: The Case of Shenzhen Special Economic Zone, ed K.Y Wong \& D.K.Y. Chu, Oxford University Press, Hong Kong.

World Trade Organization 2008, 'Trade Policy Review China, Report by the Secretariat', WT/TPR.S/199. Geneva: WTO.

- 2006 , Trade Policy Review: PRC.

- - 2001, Protocol on the Accession of the People's Republic of China, World Trade Organization.

- - 2001, Report of the Working Party on the Accession of China, World Trade Organization. 